\title{
STUDI FENOMENOLOGI : PENGALAMAN ORANG DENGAN HIV/AIDS DALAM MENCEGAH PENULARAN HIV
}

\author{
Phenomenological Study: Experience of People with HIV/AIDS in \\ Preventing HIV Transmission
}

\author{
Marthilda Suprayitna ${ }^{1}$, Agus Setiawan², Rohman Azzam ${ }^{3}$ \\ ${ }^{1}$ Program Studi D III Keperawatan, STIKES YARSI Mataram \\ ${ }^{2}$ Departemen Keperawatan Komunitas, Fakultas Keperawatan, Universitas Indonesia \\ 3Departemen Keperawatan Medikal Bedah, Fakultas Keperawatan, Universitas Muhamadyah Jakarta \\ Korespondensi : mathildasuprayitna@gmail.com
}

\begin{abstract}
ABSTRAK
Angka kejadian HIV di Kota Mataram meningkat dalam 5 tahum terakhir. Upaya yang telah dilakukan oleh Pemerintah setempat terkait penanggulangan HIV/AIDS yang sudah dilaksanakan selama ini seperti melakukan pencegahan - pencegahan pada lingkungan agar tidak terkena penularan virus HIV/AIDS melalui kampanye dan penyuluhan tentang penggunaan kondom dan melakukan pengobatan untuk mereka yang sudah positif HIV/AIDS. Tujuan penelitian ini untuk mengeksplorasi pengalaman orang dengan HIV/AIDS dalam mencegah penularan HIV. Metodologi yang digunakan adalah fenomenologi dengan jumlah partisipan sebanyak 6 orang, data dikumpulkan melalui wawancara mendalam. Wawancara direkam dan kemudian dibuat dalam bentuk verbatim. Hasil penelitian mengungkapkan variasi berbagai pengalaman orang dengan HIV/AIDS dalam mencegah penularan. Lima tema didapatkan dalam penelitian ini meliputi partisipan terdiagnosis HIV/AIDS, upaya partisipan dalam pencegahan penularan, hambatan partisipan serta motivasi partisipan dalam pencegahan penularan HIV/AIDS, dan dukungan yang diterima partisipan dalam upaya pencegahan penularan HIV. Berdasarkan temuan hasil tema tersebut disarankan agar perawat membantu upaya promosi kesehatan, partisipan mendapatkan dukungan dan motivasi untuk meningkatkan perilaku pencegahan penularan HIV/AIDS
\end{abstract}

Kata Kunci : pengalaman, HIV/AIDS, pencegahan penularan

\begin{abstract}
The Incidence of HIV in Mataram increase significantly. Efforts that have been made by local governments related to HIV / AIDS prevention in cludly undertaking preventions on environment to avoid the infection of HIV / AIDS through campaigns and counseling about using of condoms and doing treatment for those who positive of HIV / AIDS. The purpose of this research was explore the experiences of people with HIV / AIDS in preventing of HIV infection. Methodology used is phenomenology with 6 participants, data was collected through in interviews. The interviews are recorded and then transcribed. The results revealed of variations in experiences of people with HIV / AIDS in preventing of it infection. The five themes covered in this research includes participants diagnosed with HIV / AIDS, participant efforts in prevention of HIV infection, participant barriers of it, participant motivation in prevention of HIV / AIDS infection, and support received by participants in prevention of HIV infection. Based on the findings, it is suggested that nurses can assist health promotion efforts, the participants can get support and motivation to improve the prevention behavior of HIV / AIDS
\end{abstract}

Keywords: experience, HIV / AIDS, prevention of infection 


\section{PENDAHULUAN}

HIV/AIDS (Human Immunodeficiency

Virus/ Acquired Immune Deficiency Syndrome) merupakan masalah kesehatan di seluruh dunia. WHO (World Health Organization) menyatakan bahwa HIV/AIDS saat ini menjadi ancaman global dan mengakibatkan dampak merugikan di semua sektor. Infeksi oleh HIV mengakibatkan kerusakan sistem kekebalan dan pertahanan tubuh penjamu.

Penularan kasus HIV/AIDS kumulatif dilaporkan melalui Heteroseksual (68\%), IDU (12\%), Homoseksual (10\%), Perinatal (5\%) dan tidak diketahui (2\%) (KPA NTB, 2017). Perilaku pencegahan penularan HIV khususnya oleh ODHA ke orang lain sangatlah penting untuk dilakukan melalui perubahan perilaku beresiko, guna memutuskan mata rantai penularan HIV dan mengurangi dampak sosial ekonomi dari HIV/ AIDS, sehingga tidak terjadi masalah kesehatan masyarakat (Black \& Hawks, 2014; Notoatmodjo, 2012). Dimana angka kejadian HIV/AIDS setiap tahun meningkat. Sedangkan jumlah kasus HIV/AIDS di Nusa Tenggara Barat sampai Tahun 2016 sebanyak 1.265 kasus dan di Kota Mataram sebanyak 464 orang, merupakan jumlah tertinggi dari kabupaten yang ada di Nusa Tenggara Barat (KPA NTB, 2017).

HIV/AIDS sangat berisiko menular melalui kontak seksual dan nonseksual yang tidak aman dan mengancam eksistensi kehidupan manusia. Dampak penularan ini harus segera diatasi. Dari studi pendahuluan yang dilakukan di Kota Mataram didapatkan sebagian orang dengan HIV/AIDS telah melakukan upaya pencegahan penularan seperti penggunaan kondom saat berhubungan, menjaga kebersihan diri dengan baik, tidak menggunakan jarum suntik secara bergantian. Akan tetapi peningkatan jumlah orang dengan HIV/AIDS terus meningkat.

\section{TUJUAN PENELITIAN}

Penelitian ini bertujuan untuk memperoleh pemahaman yang mendalam tentang pengalaman orang dengan HIV/AIDS dalam mencegah penularan HIV di Kota Mataram.

\section{METODE PENELITIAN}

Desain

Penelitian ini menggunakan metode kualitatif dengan pendekatan fenomenologi.
Dalam studi ini yang dipelajari adalah pengalaman orang dengan HIV/AIDS dalam mencegah penularan HIV. Metode ini menitikberatkan pada arti menjadi orang dengan HIV/AIDS dalam mencegah penularan HIV. Sedangkan fenomena yang mendasarinya adalah sebagian ODHA telah melakukan pencegahan penularan HIV dengan baik tetapi terjadi peningkatan yang fluktuatif jumlah kasus HIV/AIDS. Sehingga dengan pendekatan fenomenologi diperoleh gambaran - gambaran secara menyeluruh tentang orang dengan HIV/AIDS dalam mencegah penularan HIV.

\section{Populasi dan Sampel}

Populasi dalam penelitian ini adalah orang dengan HIV/AIDS yang terdiagnosis HIV sekitar 10 bulan sampai 4 tahun. Jumlah partisipan dalam penelitian ini sebanyak 6 orang.

\section{Tempat dan Waktu Penelitian}

Penelitian ini dilaksanakan dilaksanakan di Kota Mataram pada bulan April - Juni 2017.

\section{Instrumen dan Prosedur Pengukuran}

Pada penelitian ini, peneliti merupakan bagian dari instrumen penelitian. Pengumpulan data dilakukan dengan melakukan Wawancara mendalam (indepth interview) yang dilakukan pada orang dengan HIV/AIDS untuk menggali lebih dalam perilaku pencegahan penularan HIV/AIDS. Alat pengumpul data yang digunakan diantaranya lembar pedoman wawancara, buku catatan lapangan (field note), alat tulis, alat perekam (MP3) dan panduan pertanyaan yang digunakan adalah pertanyaan terbuka (open ended interview)

\section{Analisa Data}

Pengolahan data yang dilakukan adalah dengan cara mendokumentasikan data hasil wawancara mendalam dan catatan lapangan yang diperoleh selama wawancara. Pendokumentasian hasil wawancara dilakukan dengan memutar hasil rekaman. Hasil rekaman kemudian ditulis apa adanya dan digabungkan dengan hasil catatan lapangan sehingga menjadi print out transkip.

Analisis data dalam studi kualitatif didasarkan pada penafsiran data. Peneliti menafsirkan setiap informasi yang didapatkan dari partisipan dan mencoba menyimpulkan beberapa informasi yang sesuai dengan tujuan 
penelitian. Pengolahan dan analisis meliputi Pembuatan transkip data, pembacaan transkip, pembuatan kategorisasi, penentuan kategori, formulasi tema - tema, Kluster tema, deskripsi lengkap dan terakhir laporan hasil analisis.

\section{HASIL PENELITIAN}

Karakteristik Partisipan

Usia partisipan 22 - 35 tahun dan tinggal di Kota Mataram. Latar pendidikan pendidikan mereka yaitu 5 tamaat SMU dan 1 tamat SMP. Pekerjaan partisipan bervariasi yaitu 3 swasta, 1 sopir, 1 jasa pijat dan 1 orang partisipan tidak bekerja. Status perkawinan partisipan 3 sudah menikah, 2 janda dan 1 belum menikah. Hasil wawancara lainnya yaitu partisipan telah terdiagnosis HIV sekitar 10 bulan -4 tahun.

\section{Hasil Analisa}

1. Makna kemitraan keluarga dalam Respon partisipan pertama terdiagnosis HIV/AIDS

Respon partisipan terdiagnosis

HIV/AIDS ditemukan dua respon yaitu menerima dan menolak. Respon menolak dari partisipan diantaranya menyangkal masalah, depresi, dan tawar - menawar. Respon partisipan menolak di ungkapkan salah satu nya dengan :

Saya bener tidak menyangka saya kan gak pernah berhubungan apalagi seks sembarangan kok bisa kena penyakit HIV.

Selain menolak, dua partisipan menerima dengan keadaanya sekarang. Respon penerimaan partisipan melalui kepasrahan terhadap kondisi dan keadaannya saat itu. Adapun pernyataan partisipan diantaranya :

Saya gak heran mungkin karena pergaulan muda saya yang nakal.. sekarang saya ingin mempernbaiki diri saya ke jalan Tuhan...

\section{Upaya partisipan dalam pencegahan penularan HIV/AIDS}

Partisipan yang menderita HIV/AIDS melakukan berbagai cara sehingga nanti nya tidak menularkan penyakit tersebut. Semua partisipan dalam penelitian ini melakukan pencegahan dengan menggunakan kondom jika melakukan hubungan seksual. Berikut ini adalah ungkapan partisipan tersebut :

Kalau sudah tau punya penyakit ini, ya harus pakai kondom saat berhubungan.
Selain itu ada tiga partisipan yang tidak mau melakukan donor darah, dan diungkapkan partisipan sebagai berikut :

Saya pernah diminta untuk mendonorkan darah, saya menlak.

Adapun pernyataan partisipan yaitu berusaha menghindari luka akibat benda tajam yang diungkapkan sebagai berikut :

Pernah tangan saya terluka kena pisau, anak harus jauh dari saya..

Ungkapan lain dari satu partisipan tidak memberikan ASI pada anaknya.

\section{Hambatan partisipan dalam mencegah penularan}

Hambatan - hambatan yang dirasakan oleh ODHA merupakan masalah yang terjadi selama mengalami penyakit HIV/AIDS dalam mencegah penularan. Partisipan mengalami berbagai hambatan yang berasal dari dirinya sendiri seperti fisik, psikologis dan sosial. Hambatan - hambatan tersebut dapat menganggu kehidupan dalam keluarga, maupun hidup bermasyarakat ODHA.

Hambatan fisik berupa penyakit pada sistem gastrointestinal, sistem pernapasan, sistem integumen dan kelamin. Sedangkan untuk hambatan sosial terkait dengan sikap keluarga.

\section{Motivasi partisipan}

Partisipan yang menderita HIV/AIDS menghadapi permasalahan yang komplek artinya mereka harus merasakan sakit di dalam tubuhnya yang semakin hari semakin menurun. Dari itu motivasi penderita HIV/AIDS sangat dibutuhkan untuk meningkatkan kualitas hidupnya. Motivasi partisipan diantaranya kemauan yang besar, kesadaran diri dan semangat hidup. Beberapa ungkapan pernyataan partisipan sebagai

berikut :

Kemauan untuk menjalani hidup partisipan harus dimiliki oleh seluruh penderita HIV/AIDS. Dua partisipan mengungkapkan sebagai berikut :

“.... Kemauan hidup saya yang besar, apalagi anak saya masih kecil.

"... kemauan hidup lebih lama lagi..."

\section{Dukungan yang diterima partisipan}

Dukungan sangat dibutuhkan oleh partisipan dalam mencegah penularan HIV/AIDS. Dimana dukungan yang 
diharapkan adalah baik dari keluarga inti, kerabat dari petugas kesehatan. Berikut ungkapan pernyataan partisipan :

“....saya hanya mengharapkan dukungan dari orangtua saya bu..

"...dukungan dari keluarga saya sangat saya butuhkan, hanya mereka yang memahami kondisi saya.....

\section{PEMBAHASAN}

Hasil penelitian ini menunjukkan bahwa Pada penelitian ini rekasi pertama kali terdiagnosis HIV/AIDS bermacam - macam. Setiap orang akan memberikan reaksi yang berbeda - beda pada saat mengetahui dirinya terkena HIV/AIDS. Reaksi menyangkal pada ODHA yang baru pertama kali terdiagnosa HIV/AIDS. Selain menyangkal ODHA merasa tidak percaya bahwa dirinya terkena penyakit HIV/AIDS. Hal ini dipertegas oleh pendapat oleh Kubler - Ross (1969, dalam Nursalam 2013) menyatakan bahwa reaksi pertama individu terhadap kehilangan adalah terkejut dan tidak percaya.

Secara sadar maupun tidak sadar seseorang yang berada dalah tahap menolak semua fakta, informasi dan segala sesuatu yang berhubungan dengan hal yang dialaminya. Individu merasa hidupnya tidak berarti lagi.Pada penelitian ini ditemukan respon menerima terhadap diagnosis HIV/AIDS pada dirinya. ODHA sudah memahami dan menerima keadaanya dengan perasaan terbuka. Menurut Wirawan (2009) penerimaan setelah beberapa lama, seseorang dengan HIV biasanya mulai bisa menerima keadaannya. Ini akan membantu membuat merasa lebih baik. Seperti halnya seseorang yang sudah lebih tenang pikirannya, akan mulai memikirkan jalan terbaik dalam menjalani kehidupan.

Memakai kondom diungkapkan oleh seluruh informan bahwa dapat mencegah penularan HIV/AIDS. Mereka menyadari bahwa dengan menggunakan kondom makan akan mencegah penularan HIV/AIDS. Dari penelitian epidemiologi, efektivitas kondom untuk mencegah penularan HIV mencapai $70 \%$ dengan syarat digunakan secara tepat dan konsisten (Ardyanto, 2016). Hal ini diperkuat dengan hasil penelitian bahwa sebagian faktor faktor pada level individu (pengetahuan, motivasi dan kesiapan menggunakan kondom, niat, keputusan menggunakan kondom) dalam situasi yang memadai menjadi faktor penggunaan kondom secara konsisten (Aditya, 2012).

Pada penelitian ini ditemukan bahwa ODHA tidak mendonorkan darahnya. Melakukan donor darah sangat cepat menularkan HIV karena virus langsung masuk ke pembuluh darah dan menyebar ke seluruh tubuh. Dua dari partisipan menyebutkan bahwa HIV/AIDS dapat ditularkan melalui donor darah.

Penularan HIV/AIDS salah satu nya adalah melalui alat - alat untuk menoreh kulit. Alat tajam dan runcing seperti jarum, pisau, silet, menyunat seseorang, membuat tato, memotong rambut, dan sebagainya bisa menularkan HIV sebab alat tersebut mungkin dipakai tanpa distreilkan terlebih dahulu. Dalam hal ini partisipan yang menderita HIV/AIDS terkena goresan pisau, yang bagi mereka sangat berbahaya jika sampai terkena pada keluarga mereka.

Penularan HIV dari ibu bisa terjadi pada saat kehamilan ( in utero ). Berdasarkan laporan CDC Amerika, prevalensi penularan HIV dari ibu ke bayi adalah $0,01 \%$ sampai $0,7 \%$. Bila ibu baru terinfeksi HIV dan belum ada gejala AIDS, kemungkinan bayi terinfeksi sebanyak $20 \%$ sampai $35 \%$, sedangkan kalau gejala AIDS sudah jelas pada ibu kemungkinan mencapai 50\% (PELKESI, 1995).

Temuan hasil penelitian ini sesuai dengan teori dan penelitian yang ada, hal ini disebabkan kondisi ODHA pada saat terjadi diare kronik sudah memasuki stadium AIDS sehingga memudahkan terjadinya infeksi oportunistik pada intestinum yaitu diare. Kejadian diare pada ODHA sangat membutuhkan perawatan dan terapi yang tepat karena akan mengakibatkan dehidrasi berat yang menyebabkan gagal fungsi ginjal yang berisiko kematian pada ODHA.

Orang dengan HIV/AIDS (ODHA) rentan terkena berbagai infeksi karena sistem kekebalan tubuhnya yang menurun drastis atau berhubungan dengan pengobatan. Salah satu infeksi adalah kelainan kulit muncul hampir secara umum pada perjalanan infeksi HIV. Manifestasi kulit pada infeksi HIV sangat luas dan bervariasi serta dapat disebabkan virus, bakteri, jamur, dan parasit lainnya.

Sikap keluarga yang berespon menerima keadaan karena tahu faktor risiko yang dijalani, dan menganggap bahwa penyakit merupakan ujian yang harus dijalani oleh setiap manusia. 
Keluarga memiliki kewajiban untuk merawat, Camphell (2000) menyatakan adanya penyakit yang serius dan kronik pada salah satu anggota keluarga biasanya mempunyai dampak besar pada sistem keluarga, terutama pada struktur peran dan fungsi keluarga. Keluarga merupakan penyedia pelayanan kesehatan utama yang mengalami penyakit kronik.

Motivasi adalah proses psikologis yang dapat menjelaskan perilaku seseorang. Perilaku hakikatnya merupakan orientasi pada satu tujuan. Dengan kata lain, perilaku seseorang dirancang untuk mencapai tujuan. Unsur mencapai tujuan tersebut diperlukan proses interaksi dari bebrapa unsur. Dengan demikian, motivasi merupakan kekuatan yang mendorong seseorang melakukan sesuatu untuk mencapai tujuan. Kekuatan - kekuatan ini pada dasarnya dirangsang oleh adanya berbagai macam kebutuhan seperti (1) keinginan yang hendak dipenuhinya, (2) tingkah laku, (3) tujuan, (4) umpan balik (Hamzah, 2013).

Dukungan keluarga sangat dibutuhkan karena dukungan keluarga dapat menghilangkan stress pada Orang dengan HIV/AIDS. Menurut Rodin dan Salovey (1989) dalam Nursalam (2013) dukungan terutama konteks hubungan yang akrab atau kualitas hubungan perkawinan dan keluarga merupakan sumber dukungan yang paling penting. Keluarga dihubungkan oleh ikatan yang sangat kuat, bahkan lebih kuat saat mengalami kejadian yang mengkhawatirkan. Segala hal yang menghambat semua anggota keluarga, maka akan menghambat kecemasan yang dialami individu. Dukungan keluarga diartikan sebagai bantuan orang saat menghadapi keadaan yang kurang menyenangkan dalam hidup (Na'im, 2010).

\section{KESIMPULAN \\ Implikasi}

Meningkatkan upaya promosi kesehatan tentang HIV/AIDS dan sosialisasi kepada masyarakat melalui media masa yang sering diakses oleh masyarakat, sehingga dapat mengurangi stigma negatif pada orang dengan HIV/AIDS. Adanya pendampingan secara berkala pada kelompok dukungan sebaya supaya bisa menyampaikan aspirasi orang dengan HIV/AIDS melalui advokasi pada pemerintah kabupaten setempat.

Program pendampingan kelompok sebaya dengan mendatangkan narasumber ahli akan meningkatkan pengetahuan dan pemahaman orang dengan HIV/AIDS tentang penyakit HIV/AIDS, peran dan fungsi ODHA di masyarakat yang memberikan semangat dan motivasi untuk tetap menjalankan fungsi dalam kehidupannya.

\section{Keterbatasan}

Kemampuan peneliti untuk melakukan wawancara secara mendalam dan catatan lapangan yang perlu ditingkatkan. Penelitian ini merupakan pengalaman pertama bagi peneliti dalam melakukan penelitian kualitatif dengan metode tersebut. Banyak data-data yang mungkin bisa lebih dalam penggaliannya, bila peneliti dapat meningkatkan kemampuan melakukan wawancara mendalam sambil menuliskan catatan lapangan. Peneliti sering mengalami kesulitan untuk berkonsentrasi mendengarkan pernyataan partisipan dan menuliskan respon non verbal partisipan.

Peneliti juga harus berfikir cepat dalam mencerna pernyataan yang diberikan partisipan dan kemudian menanyakan pertanyaan berikutnya untuk menggali fenomena lebih dalam. Peneliti juga merasa kesulitan menghadapi informan yang banyak bicara diluar konteks wawancara. Untuk itu peneliti harus dapat lebih meningkatkan kemampuan untuk mengaplikasikan metode penelitian kualitatif dan mencoba melakukan pengumpulan data dengan metode yang lain.

\section{DAFTAR PUSTAKA}

Adekeye, O \& Adensi, S. (2011). Attribution Patternsm And Knowledge of HIV/AIDS on Sexual Behaviour Change Among Students of Covenant University, Ota, Nigeria.

Adesla V.(2009). Resiko rentan dihadapi oleh homoseksual diperoleh dari http://www.epsikologi.com/epsi/Klinis_detail.asp?id= 566.

Aditya. (2012). Perilaku penggunaan kondom secara konsisen untuk mencegah HIV: Studi kualitatif pada pekerja seks laki laki berbasis panti pijat di Jakarta.

Afifah. (2011). Pendidikan Seks untuk Remaja.Surakarta. Gizone Publishing.

Afiyanti, Sitorus \& Vitriawan. (2007). Pengalaman Pasien Pertama Kali 
Marthilda Suprayitna, dkk: Studi Fenomenologi Pengalaman Orang dengan HIV/AIDS dalam Mencegah Penularan HIV

Terdiagnosis HIV/AIDS : Studi

Fenomenologi dalam Perspektif

Keperawatan. Jurnal Keperawatan UI.

Jakarta

Afiyanti \& Rachmawati. (2014). Metodologi Penelitian Kualitatif Dalam Riset Keperawatan. PT Raja Grafindo Persada. Jakarta

Agustriadi.O, Sutha B.I. (2008). Aspek Pulmonologis Infeksi Oportunistik pada Infeksi HIV/AIDS. Jurnal ilmu penyakit dalam. Volume 9 no 3

Ahmad Rusdi. (2012). Fenomena HIV Sebagai Sebuah Masalah dari Pencegahan yang bermasalah. Makalah mata kuliah Current Issues in Religion, Health, \& Ethnic. UIN Syarif Hidayatullah. Jakarta

Ardyanto. (2016). Kondom, Seks Bebas dan HIV. FK Universitas Negeri Surakarta. Jawa Tengah

Arifianti A. N.(2008).Analisis faktor-faktor penyebab niat wanita pekerja seks yang menderita IMS berperilaku seks aman (safe sex) dalam melayani pelanggannya. Tesis. Semarang: Pasca sarjana IKM Universitas Diponegoro. Tidak dipublikasikan.

Azwar, S. (2015). Sikap Manusia Teori dan Pengukurannya edisi ke 2. Pustaka Pelajar. Jakarta

Bare. B.G \& Smeltzer.S.C. (2002). Buku Ajar Keperawatan Medikal Bedah Brunner \& Suddarth ( Agung waluyo, Kiriasa, Julia, Y. Kuncara, Yasmin Asih, Penerjemah). Jakarta : EGC.

Black, J. M \& Hawks, J.H. (2014). Keperawatan Medikal Bedah Manajemen Klinis untuk hasil yang diharapkan. Edisi 8 Buku 3. Elsivier

Creswell, J. W. (2010). Research Design Pendekatan Kualitatif, Kuantitatif dan Mixed. Pustaka Pelajar

Depertemen Kesehatan RI. (2016). Strategi penanggulangan HIV/AIDS 2003- 2007. Jakarta : Kementrian koordinator bidang kesejahteraan raktat.

Direktorat jenderal pencegahan dan pengendalian penyakit - kementrian kesehatan . (2016). Laporan situasi perkembangan HIV/AIDS dan PIMS sd Desember 2016. Jakarta

Dorman A.(Oktober - Desember 1997). HIV Risk Behavior in Irish Intravenous Drug User. Journal Medical Science 166(4) : 235-238.

Friedman. M.M, Bowden.R.V, Jones.G.E (2010). Buku Ajar Keperawatan Keluarga riset, teori dan praktik edisi 5, Jakarta: Penerbit buku kedokteran EGC.

Gallant Joel. (2010). 100 Tanya Jawab mengenai HIVdan AIDS. Indeks. Jakarta

Hananta.D. (2009). Profil diare kronik pada penderita HIV/AIDS di rumah sakit Syaiful Anwar Malang. Skripsi. Tidak dipubikasikan.

Haryono. (2009). Pengaruh Karakteristik dan Kompensasi Tehadap Kinerja Pegawai Dengan Media Motivasi Kerja . Tesis. Tidak dipublikasikan. Universitas Stikubank Smeanrang

Huda, A. N \& Kusuma, H. (2015). Aplikasi Asuhan Keperawatan Berdasarkan Diagnosa Medis \& NANDA NIC-NOC Jilid 1. Jakarta

Iqramie.L.M (2010). Tingkat Pengetahuan, Sikap, Penerimaan Keluarga Penderita HIV/AIDS terhadap Penderita HIV/AIDS di RSU HJ Adam Malik Medan. Skripsi. Tidak dipublikasikan

Juliastika . (2011). Hubungan Pengetahuan tentang HIV/AIDS dengan Sikap dan Tindakan Penggunaan Kondom Pria dan Wanita Pekerja Seks di Kota Manado. Ejournal

Kuete, M, dkk. (2016). Research Article Differences in Knowledge, Attitude, and Behaviour towards HIV/AIDS and Sexually Transmitted Infection between Sexually Active Foreign and Chinese Medical Student. http://dx.doi.org//10.1155/2016/4524862

Kambu, Yowel. (2012). Analisis Faktor-Faktor Yang Mempengaruhi Tindakan Pencegahan Penularan HIV oleh ODHA di Sorong. Tesis (Dipublikasikan). UI. Jakarta

Kholid, Ahmad. (2015). Promosi Kesehatan dengan Pendekatan Teori Perilaku, Media dan Aplikasi. Jakarta. Rajagrafindo Persada

Kusuma Kelana. (2015). Metodologi Penelitian Keperawatan Panduan Melaksanakan 
Marthilda Suprayitna, dkk: Studi Fenomenologi Pengalaman Orang dengan HIV/AIDS dalam Mencegah Penularan HIV

dan Menerapkan Hasil Penelitian. Trans Info Media. Jakarta

KPA. ( 2017 ). Data Kasus HIV \& AIDS NTB.

Lily. (2004). Transmisi HIV dari Ibu ke Anak. Majalah kedokteran indonesia. 54

Moleong, J.M. (2004). Metodologi Penelitian Kualitatif Edisi Revisi. PT Remaja Rosdakarya Offset-Bandung.

Notoatmodjo. (2012). Metodologi Penelitian Kesehatan. Rineka Cipta. Jakarta

Noviana. (2016). Konsep HIV/AIDS Seksualitas \& Kesehatan Reproduksi. Trans Info Media. Jakarta

Nursalam, (2016). Metodologi Penelitian Ilmu Keperawatan Pedekatan Praktis Edisi 4. Salemba Medika. Jakarta

Nursalam \& Dian. (2013). Asuhan Keperawatan pada Pasien Terinfeksi. Salemba Medika. Jakarta

Mallory. (2002). Reciptory and Retaining African - American Women witn HIV in Research. W.B. Saunders Company

Otman.F.(2009). Prevalensi Kejadian Diare Kronik pada Pasien HIV/AIDS di RSUP HJ Adam Malik. Karya tulis ilmiah. Tidak dipublikasikan

Ratnaningsih. (2015). Faktor-Faktor Yang Mempengaruhi Perilaku Pencegahan HIV/AIDS Pada Wanita Pekerja Seks Komersial. Tesis (Dipublikasikan). UI. Jakarta

Rojanapithayakorn. (2006). The 100\% condom use programme in Asia.Reprod Health Matters. Nov;14(28):41 -52

Streubert, H.J \& Carpenter, D.R. (2003). Qualitative Research in Nursing. Advancing The Humanistic Imperative. Third Edition. Philadelphia: Lippincott Williams \& Wilkins.

Sastroasmoro, S \& Ismael, S. (2010). DasarDasar Metodologi Penelitian Klinis. Binarupa Aksara. Jakarta

Silalahi. (2008). Pengaruh predisposisi, pendukung, penguat terhadap tindakan pekerja seks komersial (PSK) dalam menggunakan Kondom untuk pencegahan HIV \& AIDS di Lokalisasi Teleju di Kota Pekanbaru. Tesis. Medan _USU

Simbolon.I. (2007). Pola kelainan kulit pada pasien HIVIAIDS di RSUP HJ Adam Malik. Karya tulis Ilmiah. Tidak dipublikasikan
Suryantini.(2009). Dampak HIV/AIDS dalam kehidupan . diperoleh melalui http://saveyousaveme.wordpress.com/20 09/05/12/dampak-hivaidsterhadapkehidupan/

Smith, D.K \& Herbest, JH \& Zhang, X. (2015). Condom Effectiveness for HIV Prevention by Consistency of Use Among Men Who Have Sex With Men in the United States

Suddarth \& Brunner. ( 2014 ). Keperawatan Medikal Bedah Edisi 12. EGC. Jakarta

Sugiyono. (2017). Metode Penelitian Kuantitatif Kualitatif dan $R \& D$. Bandung. Alfabeta

UNAIDS. ( 2016 ). Global AIDS Up Date 2016. Jakarta

Universitas Indonesia. (2005).Ketetapan Majelis Wali Amanat Universitas Indonesia No.007/TAP/MWA-UI/2005 tentang Etika Penelitian Bagi Setiap Sivitas Universitas Indonesia. (Online), diperoleh dari www.webdev.ui.ac.id/download/files/m $\mathrm{wa} / 2005$

Van Manen. (2011). Phenomenology of practice. Phenomenology \& Practice. 1(1), $11-30$

Zafar, M, Nisar, Kadir, M \& et al. (2014). Knowledge,Attitude and Practices regarding HIV/AIDS among adult fishermen in coastal areas of Karachi. http://www.biomedcentral.com/1471 $2458 / 14 / 437$ 